\title{
Diffuse materiality in public spaces between expressiveness and performance
}

\section{Gerosa, Giulia; Daglio, Laura}

Resumen: Hoy en día, el design de los espacios públicos es frecuentemente aproximado como los interiores de design urbano, con tal que la instalación y l'ajustamento de los espacios abiertos con el método y concepto parecido a los de interiores. En el papel se analiza el uso innovador de los materiales tradicionales o el uso de nuevo materiales en espacios públicos, destacando dos tendencias posibles en busca de mejorar la calidad de los espacios urbanos: expresividad y funcionamiento. Estudios de casos seleccionados son revelados de presentar como las nuevas formas, una tensión en los valores de percepción y el impacto medioambiental y comodidad tanta como durabilidad son los principales objetivos de innovación de materiales en este campo.

Palabras clave: Expresividad - rendimiento - materiales - diseño de interiores - espacio público - identidad bienestar

(*) Architect and PhD in Industrial Design and Multimedia Communication is an assistant professor in Interior design at the Politecnico di Milano where she works on research issues concerning the communicative component of the architectural project and the brand identity in retail spaces. She is involved in research programmes funded by Public Bodies at different levels and in international projects. She is the author of books, essays, articles in reviews and of academic papers presented at international Seminars.

$\left.{ }^{* *}\right) \mathrm{PhD}$ is a registered architect and an associate professor of Architectural Technology at the Politecnico di Milano where she works on research issues concerning environmental design and sustainability in architecture, at different scales, related to new construction as well as renovation. She is involved in research programmes 
funded by Public Bodies at different levels and in international projects. She is the author of books, essays, articles in reviews and of academic papers presented at international Seminars

Point of contact with the user who is immersed within it, interior space assumes the right value when architecture is conceived as the space where life is carried out, a concept extensively developed by Carlo de Carli in his theory of the "primary space", the relation space where actions are accomplished making sense of the space itself. Bruno Zevi declared first that architecture exists when there is interior space, whether it is in a building or in a city and that it acquires a value only when used by people. Starting with the assumption that interior architecture occurs when there is a space which can be entered, the scope of the discipline broadens to include all the environments where users take action, encompassing private and public spaces, residential and working spaces, health, retail, transport and accommodation facilities.

Moreover, functional instability and a growing trend from monofunctional towards multifunctional space are characteristics of contemporary architecture leading to the need of a reconsideration of the role of interiors. As highlighted by Andrea Branzi: ... there is in fact no function, program or urban zoning which hasn't been denied in the last ten years; the decommissioning of industrial facilities is the first and more obvious phenomenon of a process involving the other urban functions, from retail to housing from offices to services. People work at home, live in offices, do business in their houses, study in factories and gasometers are converted in museums... (Branzi, 2004)

Temporary settlements within specific spaces can be observed, as well as the specific design of spaces based on a predetermined lifecycle typical of industrial design, applied to containers of functions where more and more frequently also the dismantling and the total or partial recycle of the structure are programmed in advance. The time variable is declined according to different meanings leading to examples of temporary, transformable or transportable spaces up to temporary or ephemeral installations related to the phenomenon of the city of events where great flows of transient visitors experience a changing and poriferous city which quickly responds to momentary needs. The resulting projects are thus more aimed at reinventing rather than interpreting places through the fitting of new functions and new forms with the infinite freedom of a set up design approach.

Public spaces are rendered as urban interiors where to create new artifices, installations and the setting up of a renovated urban symbolism interpreting the issues of contemporary society which means temporariness and flexibility, but they are also simultaneously civic spaces as well as related to a heideggerian concept of living, and therefore should respond to the need of building a collective identity and of developing a sense of belonging in relationship to the sense of place. "Living is being at home everywhere" (La Pietra, 1977-79). The complexity and the contradictions of this double approach, combining the temporariness of installations with the durability entailed by the shared values of citizenship and urbanity, is also recognizable in the choice and use of materials and technologies1. A considerable role in the design of public spaces is in fact played by the application of new materials and the new application of traditional materials as well as by technologies for environmental comfort and by services to enrich the use and fruition of space leading to the enhancement of both the physical and the sensorial ergonomics of space, related to its evocative and communication aspects.

Two are the possible trends which an analysis and evaluation of recent projects of public spaces may offer: solutions with a high added value show typical and substantial qualities that affect expressiveness and performance. 
Regarding the urban design approach, Kevin Lynch (1960) wrote about the necessity of providing a new meaning to the cities where the user isn't able anymore to recognise himself in the historic monuments, but needs instead new signs to be oriented in the urban texture; Lynch thus underlines the concept of readability of a place, in other words the ability of the community to adapt, orientate and understand a specific urban space.

The goal of providing a strong sense of identity to the places with or without a relationship to the existing context is also achieved through the use of iconic forms or sometimes interactive devices creating a dialogue between user and space and frequently through amazing and astonishing solutions.

Historically used, light as construction material can still transform and make sense of the urban space, allowing for the "rebirth" of abandoned buildings. It's the case of the Overhead Crane in Sesto San Giovanni (2006), an extremely important part of the manufacturing history characterising Italian industrial landscape, which becomes a monumental element in the ex-Breda Industrial Archaeology Park. Today it's a symbol of the transformations which the town has experienced: a reminder of the great factories but, at the same time, also a challenge set by the new schemes for interpreting the urban spaces freed of the sheds and the impenetrable walls which enclosed those factories and hid them from view, a concept stressed by the evocative red LED lighting at night.

A similar approach can be recognised in Valle Sophie's project for the conversion of 1980s petrol station canopies into new landmarks highlighting the entrance to the new Noorderpark in Amsterdam. False ceilings of light were installed to replicate artificial skies where 20 different light animations shelter different kinds of open-air cultural activities. Daan Roosegaarde proposes instead with the Dune project (2012), in Rotterdam, a different use of light more in relationship with the natural landscape: a public interactive landscape along the river that interacts with human behaviour. This hybrid of nature and technology is composed of large amounts of fibres that brighten only according to the sounds and motions of the passing visitors.

In addition, colour is often used as a tool for modifying perceptively the space, whether in a punctual way, as in the "Magic Blocks" (Institutul Cultural Roman - Programul Cantemir, ERSTE Stiftung, Bucharest 2010) or in a diffused way, as in the Superkilen project (Topotek, Copenhagen, 2012). In the first case, a limited, symbolic response to a problem that is both huge and serious, the bright optimistic orange unifying the interventions, not only points out but also presents the problematic areas as spaces of opportunity. In the second case the space is conceived as a giant exhibition of urban best practice, a sort of collection of globally found objects coming from the 60 different nationalities of the immigrants inhabiting the area, celebrating diversity and creating a new identity of the public space underlined by the red colour.

A shifting perception of space can often be found in projects using mirroring surfaces, changing the environment according to the density of the people present throughout the day, also disclosing an atmospheric scan of the space. In the new Els Encants market in Barcelona (2014) b720 Fermin Vazquez Arquitectos design a giant canopy clad with triangular facets of polished, gilded stainless steel to reflect the activities below like a broken mirror, a kaleidoscopic ceiling. The ephemeral structure of the Serpentine Gallery Pavilion (SANAA, 2009) adopts reflective materials to create a seamless natural landscape mirroring both the park and the sky around it. 
Finally, public spaces are designed with a holistic approach involving the perception of different senses, adopting design attitudes typical of the interiors, as in the Beatbox Olympic Pavilion in London (Asif Kahn and Pernilla Ohrstedt, 2012), an experimental fusion of architecture and technology that creates a multi-sensory experience combining technology, sound, and light. The circular walls were covered in ETFE (Ethylene tetrafluoroethylene) plastic pillows that are sensitive to both movement and touch and the 230 red and white cushions that incorporate audio and interaction technology, enabling visitors to create a musical collage of sounds. The Horticultural Spa \& Apothecary Experience (2015), developed by the London firm Loop.pH, is an inflatable plastic dome pumped full of scented vapour to create a gathering space intended to replicate the atmosphere of a traditional bathhouse. In this case also the music was designed in order to create a global experience: in fact the soundtrack will be provided by a sonic artist who generates music from the electro-magnetic emissions of plants.

A second path towards the development of amazing spaces with a strong identity is pushing form and expressiveness of language to the extreme through the reinterpretation of existing traditional materials or new materials.

Computer numerical control machines and digital design allows in fact to obtain tailormade materials as the Ombrae panels that reproduce digital images by using threedimensional pixels or the traditional wire fence which becomes decorative as it can reproduce any kind of pattern typical of lace as in the Bicycle Apple in Alphen aan den Rijn (Kuiper Compagnons, 2011).

Poor materials can be used to fit up spaces that can become manifest to communicate a lifestyle mindful of civic values with regard to the urban space, as in the "Place au Changement" (Change Square) project in SaintÉtienne (2011), in which residents were asked to take part in a project of constructing a new space using durable materials and simple techniques that anyone could manage.

This is evidence of the prolonged debate taking into account the interests lurking behind urban transformations, their economic, political and social effects and the ways in which people can get prepared to influence the destiny of their cities.

\section{Performance}

As the quality of public space in our towns and cities has a positive impact on the wellbeing of residents and visitors, the quest for the performance enhancement in public spaces design embraces all the different aspects of quality and is thoroughly influenced by the principles of sustainability as an essential character of contemporary culture. The control and improvement of environmental comfort of open public spaces is thus achieved also through the rediscovery of natural materials such as water and vegetation2, though revisited through new technologies and integrated solutions. The steel structures of the Eco Boulevard in Vallecas (Ecosistema Urbano, 2007) support climbing plants and water vaporizers to cool through evapotranspiration processes the harsh summer climate of continental Spain. In Tooley Street, London, a temporary, mobile miniature modular park (WMB Studio, 2015) offers plant-covered seating for passersby providing a shelter against the polluting and noisy traffic and also monitors air quality sending data back to an app and website. Vegetation and water are used not only within environmental comfort strategies but become construction and design materials such as in the MFOPark in Zurich (Burckhardt+Partner, 2002) creating a new living multi-storey interior, or in Patrick Blanc installations or in the jardín vertical y plaza pública delicias in Zaragoza, (Sicilia y Asociados Arquitectura, 2008): 
a metal structure containing an accessible hanging garden which hides two flank walls that were an eyesore in the urban landscape. In Herbert Dreiseitl urban parks water and green are not just design features but fundamental instruments to control the hydrology of the place and to create climate adaptive and resilient cities; moreover the irrigation system at the Thermal Orchards in Caldes de Montbui waterways recovery is not just the main focus of the intervention but it also reactivates agricultural activity with both social and environmental sustainability goals.

The research for materials with a high durability has always been a special target of open spaces design, less engaged in program, structure and client as in architectural design but certainly focusing on the effects of weathering and ageing due to climate and intensive use. Technological innovation is oriented mainly towards the augmentation of natural materials to become artificial or the creation of new polymeric compounds assessing once more the preponderance of chemical industry in the construction sector. Wood for example is specially thermo treated to reach the same properties of the tropical species for long lasting street furniture or is modified (e.g. acetylated wood) to optimize its dimensional stability, durability and paint retention to be used in extreme conditions such as in the underwater structure of the Moses Bridge in Halsteren (RO\&AD Architecten, 2011). A new ultra high performance concrete (UHPC) is now commonly used for products, proprietary components or customized projects as it is 6 to 8 times stronger than conventional concrete, ductile, containing metal fibres, and resistant to external aggressions such as abrasion, pollution, weathering and scratching; its special properties are highlighted for instance in the h2o bench, a modular furniture system designed for the main square of Valenciennes in northern France by h2o Architectes in 2008. Also biodynamic and photocatalytic concrete used for paving blocks allow the transformation of harmful organic and inorganic matters into harmless compounds in order to diminish air pollutants.

Self-cleaning coatings can preserve aesthetical quality over time and new varnishes and lacquers have been developed in order to cope with the second type of threats towards the permanence of finishes and installations due to man's action: graffiti and vandalism. High performance transparent panels can replace glass thanks to the durability and the versatility of the applications as seen for example in the polycarbonate San Francisco Transit bus shelters (Lundberg Design, 2009-13), which also embeds a photovoltaic film and provides free public Wi-Fi. The multi-functionality of these canopies also introduces two other important fields of performance enhancement: fruition and energy production. The urban interiors are in fact more and more fitted with cutting edge digital technologies for Wi-Fi connection as well as augmented reality, almost erasing the differences with our homes equipment and also improving accessibility for the disabled as in the Responsive Street Furniture project by designers Ross Atkin and Jonathan Scott presented at Designs of the Year exhibition at London's Design Museum in 2015.

Energy production together with resources and materials conservation are clear manifestos of sustainability issues. Though integrated photovoltaic cells are the main feature of covers and canopies in significant urban design projects (e.g. Martínez Lapeña - Torres Arquitectos, Photovoltaic power plant, Barcelona, 2004 or the Photovoltaic canopy in Figueres by Rafael de Cáceres \& Xavier de Cáceres, 2011), the industrial design research of PV integrated components (especially street lights) can be considerably enlarged and improved.

If reducing the consumption of material is one of the advantages of special construction technologies such as inflatable structures (e.g. BIG's Bubble cloud inflatable pavilion in Roskilde for the 2016 Music-Festival in Denmark) the environmental impact control through recycle, upcycle and reuse of materials makes the 
sustainability concept more straightforward. Though some new materials for urban design produced through recycle technologies are yet to be improved from the aesthetical point of view (especially from plastics and tires) reuse and upcycle practices can be witnessed especially in participated public spaces redevelopment initiatives involving citizens through self-build or selfmanagement activities. Old furniture and recycled construction materials were used in the workshop of the Cantiere Barca Project in Turin (raumlabor Berlin, 2013) and also in the Campo de Cebada in Madrid (El Campo De Cebada, 2010).

In the design of temporary pavilions and installations the short life of the construction inspires the use of recyclable or low impact materials such as in the I love Green installation (2A+P, Rome, 2007), involving the use of vegetation and rough wood planks. In the MoMA PS1 gallery pavilion (The Living, New York 2014) this concept is brought to the extreme consequences: the structure is built entirely from biodegradable materials; each of the bricks used to construct it were grown rather than manufactured, using a combination of agricultural by products and mushroom mycelium, allowing for its natural degradation and melting within a few weeks.

As the civic character of public space summons the representation of community and citizenship, the use of materials can acquire an instrumental role in terms of communication and promotion for sharing social and environmental values. It's the case of the Stylized Trash outdoor furniture by Designo Patagonia, in Argentina, displaying perfectly clean recyclable paper, tin, glass, pet, nylon, expanded polystyrene, aluminium and tetrabrick, with the aim of helping people understand that rubbish can be a precious raw material.

The prevalence of the ethical message triggers a possible question whether the materials used in the design of these spaces should be simultaneously beautiful (expressive), right (environmentally sustainable) and good (high performance). A further consideration addressing the sense of belonging to be encouraged by urban public spaces, focuses on the material identity of the place. The quest for innovation towards performance enhancement or, conversely, cost control restraints, favouring cheaper foreign stones imports from other continents, also poses consistent questions whether genius loci also involving the use and interpretation of local traditional materials cannot still be considered as a design inspiration to convey sense of place and identity. But how can we redefine the idea of identity in an era of globalization?

Notas

1. "Some are spaces for the public and others are urban public spaces. Public space combines "urban things", physical materials that are able to make perceptible an idea of the city. Hegel said that beauty is the perceptible expression of an idea. And this is the grandeur and difficulty of public spaces. Ground and mud, cobblestones and slabs, asphalt and concrete, wood and leaves on the trees shift here from being generic to components for making urban quality a material thing. Walls, land, lamp posts, doorways, ramps, vehicles, corners and crannies establish the sensations of the mind that bring people into relation". (Solà Morales, 2010)

2. The first contemporary solutions and experimentations date back to Expo '92 in Seville.

\section{References}

Branzi, A. (april 2004). L'autonomia del Design degli interni, AL mensile di informazione degli architetti lombardi, n.4, Milano. 
De Giorgi, G. (2005). Nuovi interni metropolitani Interni Urbani,ArchitetturaCittà - rivista di architettura e cultura urbana, Torino, Agorà edizioni.

de Solà-Morales, M. (2010). The impossible project of public space, 2010, (available at: http:// www.publicspace.org/en/text-library/eng/c006-I-impossible-projecte-de-l-espai-public, accessed July 13th 2016)

La Pietra, U. (2013). Interno / Esterno. Per arredare e abitare la città, La Pietra U., Attrezzature urbane per la collettività, Mantova, Corraini.

Lynch, K. (1960). The Image of the City. Cambridge MA, MIT Press.

Docci, M. (2005). Interni urbani, Interni Urbani, ArchitetturaCittà - rivista di architettura e cultura urbana, Torino, Agorà edizioni. Giuffrè, R. (2005). Fra antinomia e tecnologia. Un problema di spazialità diffusa, Interni Urbani,ArchitetturaCittà - rivista di architettura e cultura urbana, Torino, Agorà edizioni.

Lamunière, J. M. (2005). Interni urbani. Miti generativi, Interni Urbani, ArchitetturaCittà - rivista di architettura e cultura urbana, Torino, Agorà edizioni.

\section{Abstract:}

Public spaces design is today frequently approached as urban interiors design where to create new artifices and the setting up of a renovated urban symbolism providing the installation and the fitting up of open spaces with methods and concepts akin to those of Interiors. The paper discusses the innovative use of traditional materials or the use of new materials in public spaces design, highlighting two possible trends in the search for the quality enhancement of urban places: expressiveness and performance. Selected case studies are disclosed to present how new forms, a stress on perceptual values and the environmental impact and comfort as well as durability are the main goals of material innovation in this field.

Key words: Expressiveness - performance - materials - interior design - public space - identity - wellbeing

Resumo: O Design de espaços públicos é hoje muitas vezes tratado como design interior urbano, onde os novos recursos são criados e um simbolismo renovado é estabelecido proporcionando espaços abertos com métodos semelhantes aos conceitos de interiores. Este artigo discute o uso inovador de materiais tradicionais e o uso de novos materiais na concepção de espaços públicos, incluindo duas possíveis tendências na busca da melhoria da qualidade dos espaços urbanos: a expressividade e o desempenho. São apresentados estudos de casos para mostrar como as novas formas, a ênfase nos valores perceptuais, impacto ambiental, o conforto, e a durabilidade são os principais objetivos da inovação de materiais neste campo.

Palavras chave: expressividade - desempenho - materiais - design de interiores - espaço público - identidade bem-estar.

Diffuse materiality in public spaces between expressiveness and performance fue publicado de la página 117 a página124 en Cuadernos del Centro de Estudios de Diseño y Comunicación №70 